\title{
Inner cannula aspiration in a laryngectomized patient: a case report
}

\author{
Total larenjektomili hastada iç kanül aspirasyonu: Olgu sunumu \\ Zafer Hırçın, Görkem Eskiizmir \\ Department of Otorbinolaryngology, Faculty of Medicine, Celal Bayar University, Manisa, Turkey
}

\begin{abstract}
In laryngectomized patients, foreign body aspiration into the tracheobronchial system is an emergency condition and may cause acute respiratory distress; although it is very rare. In this case report, symptomatology, diagnostic evaluation and treatment modality of a laryngectomized patient who had inner cannula aspiration into the tracheobronchial system were presented.
\end{abstract}

Key words: Foreign body, laryngectomy, tracheostomy.

Foreign body $(\mathrm{FB})$ aspiration into the tracheobronchial system is an emergency condition which has high morbidity and/or mortality. Although it commonly occurs in children, it may also occur in adults especially the cases with several predisposing factors which impair the protective airway mechanism. In the largest series of adults with FB, $41.7 \%$ of patients had predisposing factors such as primary neurologic disorders, a loss of consciousness due to trauma, and the use of sedatives or alcohol. ${ }^{[1]}$

Herein, we presented an unusual case report of a inner cannula aspiration into the tracheobronchial system of a laryngectomized patient.

\section{Case Report}

A 58-year-old man, who had undergone total laryngectomy 7 years ago in another medical center, applied to the Emergency department with slight respiratory distress. His complaint was started just after the aspiration of his inner cannula which's side was fractured accidentally. The patient mentioned that he was using the cannula to avoid the stom-

\begin{abstract}
Özet
Lajenjektomi yapılmış kişilerde trakeobronşial sisteme yabancı cisim aspirasyonu, sık karşılaşılmayan bir durumdur. Ancak olduğunda, akut solunum sıkıntısı yaratacağı için çok acil girişim gerektirmektedir. Bu olgu sunumunda, trakeostomi kanülünün iç bölümünü aspire eden bir hastamızın semptomları, tanı ve tedavi yöntemlerimiz sunulmuştur.
\end{abstract}

Anahtar sözcükler: Yabancı cisim, larenjektomi, trakeostomi.

al narrowing. Nevertheless, the width of his stoma was $7 \mathrm{~mm}$, therefore he could not use the external part of the cannula which had a width of $9 \mathrm{~mm}$. Unfortunately, he did not apply to a medical center for his stomal stricture. The presence of FB in the tracheal lumen was demonstrated and recorded by using portable endoscopic imaging system (endogo ${ }^{\circledR}$ Portable Endoscopic Imaging System, Medtronic Inc., Minneapolis, MN, USA). In addition, the chest X-ray revealed the presence of cannula at the carina (Fig. 1a). Initially patient was monitored and the tracheostoma was infiltrated with $1 \%$ lidocaine with 1:100,000 adrenaline for regional anesthesia. Subsequently, inner cannula was extracted with powerful bronchoscopy forceps (Karl Storz 10371 HL, Tuttlingen, Germany) (Fig. 1b). The complaints of the patient was relieved simultaneously, and no major or minor complication was observed afterwards.

\section{Discussion}

The presence of permanent tracheal stoma in laryngectomized patients is a predisposing factor for FB aspiration,
Correspondence: Zafer Hırçın, MD. Department of Otorhinolaryngology, Faculty of Medicine,

Celal Bayar University, 45010, Manisa, Turkey.

e-posta: zafermedege@yahoo.com

Received: June 14, 2013; Accepted: July 12, 2013; Published online: November 1, 2013
Online available at:

www.jmedupdates.org doi:10.2399/jmu.2013002010 QR code: 

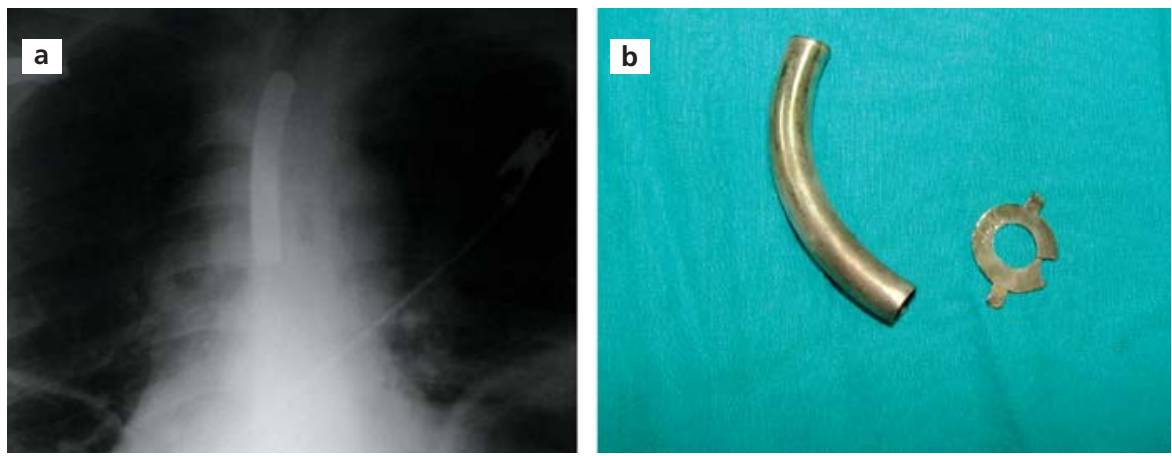

Fig. 1. The chest X-ray demonstrates the presence of inner cannula at the carina (a). The extracted inner cannula (b)

although it is very rare. In our literature survey with the keywords of "foreign", "body" and "laryngectomized", only 8 case reports in which FB aspiration into the tracheobronchial system in laryngectomized patients were found. The FB, which were extracted in these cases, were wooden stick, brush, nail and safety pin. Interestingly, there is only one similar case in which a laryngectomized patient aspirated the cannula; therefore, our case is the second laryngectomized patient with inner cannula aspiration. ${ }^{[2]}$

The classical triad of FB aspiration into the tracheobronchial system is cough, dyspnea and cyanosis, which may need urgent management. Fortunately, our case did not have a significant respiratory distress, thereby a detailed physical examination by using flexible endoscope and radiological evaluation were performed preoperatively. The endoscopic examination of the tracheobronchial system demonstrated a firmly impacted inner cannula at the carina. Although the inner cannula was definitely seen under endoscopic examination, chest $\mathrm{X}$-ray was performed for the evaluation of the tracheobronchial system. As Ramos RM et al. emphasized chest X-ray has a great accuracy for the identification of metallic $\mathrm{FB} \cdot{ }^{[3]}$ In the chest X-ray of our patient, the presence of inner cannula at the carina was confirmed and presence of other FB was excluded (Fig. 1b).

The extraction of FB from the tracheobronchial system can be performed by flexible bronchoscopy, rigid bronchoscopy, or thoracotomy according to the nature and location of the $\mathrm{FB} .^{[4]}$ In laryngectomized patients, performing rigid bronchoscopy through tracheal stoma is considerably difficult, because of interference from the chin. In addition, in laryngectomized patients like our case, the presence of stomal narrowing precludes the passage of scope. Therefore, flexible endoscope, which can be easily applied under regional anesthesia, was preferred for the extraction of inner cannula. This technique is effective, easy to perform and can be applied under regional anesthesia with minimal complication risk. However, if this procedure failed, bronchoscopic extraction of foreign body under jet ventilation could be a second option.

In laryngectomized patients with permanent tracheostoma, the potential risk of $\mathrm{FB}$ aspiration into the tracheobronchial system is remarkably high. Therefore, this complication should be explained to the patients as a part of their rehabilitation protocol.

Conflict of Interest: No conflicts declared.

\section{References}

1. Limper AH, Prakash UB. Tracheobronchial foreign bodies in adults. Ann Intern Med 1990;112:604-9.

2. Rodriguez IE, Galan LS, Lopez MZ, et al. Tracheobronchial foreign body in the laryngectomized patient. [Article in Spanish] An Otorrinolaringol Ibero Am 1998;25:185-92.

3. Ramos MB, Fernandez-Villar A, Rivo JE. Extraction of airway foreign bodies in adults: experience from 1987-2008. Interact CardioVasc Thorac Surg 2009;9:402-5.

4. Nwiloh J, Fotrson J. Aspirated foreign body in a laryngectomized patient: case report and literature review. Ear Nose Throat J 2001; $80: 744-8$.

This is an open access article distributed under the terms of the Creative Commons Attribution-NonCommercial-NoDerivs 3.0 Unported (CC BYNC-ND3.0) Licence (http://creativecommons.org/licenses/by-nc-nd/3.0/) which permits unrestricted noncommercial use, distribution, and reproduction in any medium, provided the original work is properly cited.

Please cite this article as: Hırçın Z, Eskiizmir G. Inner cannula aspiration in a laryngectomized patient: a case report. J Med Updates 2013;3(2):96-97. 